Communications in Information Literacy

\title{
Review: Learning Beyond the Classroom: Engaging Students in Information Literacy through Co- Curricular Activities
}

\author{
Megan Toups \\ Saint Louis University, megan.toups@slu.edu
}

Follow this and additional works at: https://pdxscholar.library.pdx.edu/comminfolit

\section{Let us know how access to this document benefits you.}

\section{Recommended Citation}

Toups, M. (2020). Review: Learning Beyond the Classroom: Engaging Students in Information Literacy through Co-Curricular Activities. Communications in Information Literacy, 14 (2), 395-399.

https://doi.org/10.15760/comminfolit.2020.14.2.13 


\title{
Review: Learning Beyond the Classroom: Engaging Students in Information Literacy through Co-Curricular Activities, edited by Silvia Vong and Manda Vrkljan
}

\author{
Reviewed by Megan Toups, Saint Louis University
}

Keywords: book review, information literacy, co-curricular activities, case studies, outreach, Learning Beyond the Classroom: Engaging Students in Information Literacy through Co-Curricular Activities (book)

\section{Book Reviews edited by Jacqulyn Ann Williams}

Toups, M. (2020). Review of the book Learning Beyond the Classroom: Engaging students in information literacy through co-curricular activities, edited by Silvia Vong and Manda Vrkljan. Communications in Information Literacy, 14(2), 395-399.

\footnotetext{
Copyright for articles published in Communications in Information Literacy is retained by the author(s). Author(s) also extend to Communications in Information Literacy the right to redistribute this article via other scholarly resources and bibliographic databases. This extension allows the authors' copyrighted content to be included in some databases that are distributed and maintained by for-profit companies. All other rights of redistribution are licensed by Communications in Information Literacy under Creative Commons Attribution-NonCommercial-ShareAlike 4.0 International (CC BY-NC-SA 4.0).
} 


\section{Review: Learning Beyond the Classroom: Engaging Students in Information Literacy through Co-Curricular Activities, edited by Silvia Vong and Manda Vrkljan}

The focus of information literacy instruction is often isolated to the classroom, whether that instruction comes in the form of a one-shot class or a credit bearing course. However, there is significant untapped potential in incorporating library instruction and information literacy into student activities outside of the formal classroom. Librarians work in a liminal space in universities and are involved in the broader mission of supporting students' education, but they are not bound to specific disciplines. Librarians' unique position in the university allows us to collaborate on efforts that connect students to educational opportunities outside of the classroom. These activities can include student employment, study abroad programs, internships, and student leadership activities. Activities that were once considered "extracurricular" are now considered "co-curricular" in order to distinguish the importance their role has in the education of the student. An information literacy component often enhances these programs, and all librarians, not just those in instruction or information literacy positions, have the potential to support these co-curricular student educational opportunities.

In their new book, Learning Beyond the Classroom: Engaging Students in Information Literacy through Co-Curricular Activities, editors Silvia Vong and Manda Vrkljan note that the term co-curricular in higher education "is often referred to as activities or programs for students that exist outside of their coursework with intentional learning and development" (p. vii). Some examples from the book include holding workshops on the scholarly communications process for students creating posters for an undergraduate research program, data management training sessions for campus hackathons, and teaching archival literacy as part of on the job training for student assistants working in archives and special collections. Silvia Vong (head of public services) and Manda Vrkljan (InfoExpress coordinator), both from the University of St. Michael's College in the University of Toronto, have brought together a range of case studies from different authors that show us how information literacy instruction has been integrated into applied and experiential learning opportunities. These illustrations provide the reader with a source of ideas and inspiration for how one might get involved in co-curricular programs and activities at one's own institution.

\section{Toups}

Review: Learning Beyond the Classroom 
The essays in Learning Beyond the Classroom: Engaging Students in Information Literacy through Co-Curricular Activities are divided into four sections. In the first, Campus Connections, the case studies focus on co-curricular activities that combine the library and information literacy with other departments and institutions at the university. In the second section, Employment Experience, the focus shifts to how one can use library employment as a way to instill workplace information literacy skills and concepts. The third section, Innovative Initiatives, extends the engagement of students with information literacy concepts to activities beyond the traditional classroom or even formal university initiatives. The Assessment Approaches section, the last collection of essays, is shorter than the others and focuses on two academic libraries' involvement in the evaluation of co-curricular activities. An element of most of the essays is the idea that reflection is an essential part of the services offered to support student information literacy in co-curricular activities, and Chapter 13, entitled "Embedding Intentional Reflection Activities to Build Critical-Thinking Skills," is entirely devoted to the notion of reflection as a deliberate pedagogy to promote skills development. Every chapter has its own Creative Commons license which makes the practical appendices available in some chapters especially valuable for other practitioners. Every chapter ends with an extensive references section and some chapters provide recommended reading as well.

Learning Beyond the Classroom: Engaging Students in Information Literacy through Co-Curricular Activities is not a practical how-to guide in weaving information literacy into co-curricular activities. By their very nature, co-curricular activities vary widely between and within institutions, and their focus, format, and success depend largely on the context of a specific institution or program. For example, in "Fostering International Students' Academic Transformation Using Information Literacy Programming” (Chapter 9), the focus on international students may not be useful at a school with a very small international student population. However, some of the ideas and lessons learned in that chapter are transferrable to other programs, such as the importance of advocating for a program by linking it to a library's strategic plan. Some of the chapters do provide concrete resources to assist in the creation of similar activities at other institutions. In Chapter 10, "Zines as Critical Praxis: Collapsing Discourses Around Who Owns Knowledge, and What it Means to be an Author," Madeline Veitch and Lydia Willoughby provide an "Action Appendix" that includes what can go in a zine supply cart, what to put in a zine kit, how to start a circulating typewriter program, and community engaged tips and tricks for zine programming. This kind of information can help librarians looking to start a similar project 
at their institution. The strength of this book lies in how the information in these case studies is presented. The essays balance a presentation of the work of specific libraries and their partners, while also connecting these programs to broader concepts. This gives the reader an opportunity to extrapolate useful ideas that can inform their own involvement in co-curricular activities at their campuses.

In addition, many of the case studies draw explicit connections between the ACRL Framework for Information Literacy for Higher Education and the projects presented. This is both a positive and negative quality in these case studies. In a few of the essays, the mapping of the Framework concepts onto the projects seems forced, detracting attention away from the initiatives themselves, which could stand on their own without an explicit corollary threshold concept. For example, in Chapter 8, "Library Labyrinth: Strategic Exploration in a Library Escape Room," Michelle Ashley Gohr (first-year experience librarian at Arizona State University) presents a creative idea in how to incorporate escape rooms into cocurricular activities to teach information literacy skills. However, she maps "Searching as Strategic Exploration," "Information Has Value," "Authority is Constructed and Contextual," and "Scholarship as Conversation" onto this activity, depending on how the escape rooms are used. As a reader, the connections between escape rooms and information literacy would be clearer if she had kept her focus on the "Searching as Strategic Exploration" frame rather than connecting escape rooms to four out of the six frames. While the first frame presented, "Searching as Strategic Exploration," is a natural fit, the other three are tangential and detract from the presentation of an interesting idea. In other chapters, however, the Framework adds value to the presentation of the case study in one of two ways. In some cases, the connection to the Framework has practical applications in the design of the activity, such as assisting in the creation of learning goals. In other cases, showing an explicit connection to the Framework helps the reader to think about how to advocate to administrators why it is valuable to students, the library, and the university, for libraries and librarians to be involved in co-curricular activities. For example, in Chapter 7, "The Student Friends of the John M. Kelly Library: Workplace Information Literacy Through Philanthropic Activities," Manda Vrkljan maps each step of the work the students do to the Framework's threshold concepts. The author discusses how the Student Friends who are sorting book donations are engaged with concepts such as "Research as Inquiry" since the students must engage in research activities to determine the value and classification of materials.

\section{Toups}

Review: Learning Beyond the Classroom 
Librarians do not just serve the library's mission but also the university's mission to educate students into lifelong learners and critical thinkers as well. Collaboration with co-curricular programs is one way that librarians can help students to become critical thinkers and to broaden their experience with information literacy beyond classroom exercises such as evaluating information for use in a research paper. By incorporating information literacy into co-curricular programs, librarians provide students the opportunity to exercise these concepts in situations that are relevant to their lives outside the classroom.

Learning Beyond the Classroom: Engaging Students in Information Literacy through Co-Curricular Activities is a welcome addition to a growing body of work devoted to the exploration of how to connect students to the library in different contexts beyond the formal classroom. For those librarians and library staff, particularly those working in instruction and information literacy, wishing to see successful examples of these types of activities and partnerships, this book will be useful in providing ideas and inspiration. In addition, because of the diverse nature of co-curricular activities, librarians with other specialties can be inspired to get involved as well. The case studies also provide justification for why information literacy integration into co-curricular activities is an important way that librarians can support student learning. This makes the book a valuable tool in advocating to administrators why a librarian should be given the time and resources to work with such programs and projects. 